ELORE (ISSN 1456-3010), vol. $17-1 / 2010$.

Julkaisija: Suomen Kansantietouden Tutkijain Seura ry.

[http://www.elore.fi/arkisto/1_10/kirjat_saarikoski_1_10.pdf]

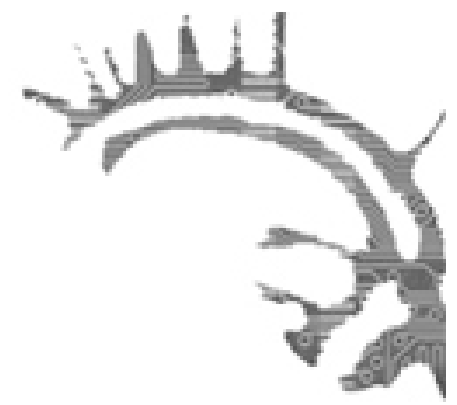

\title{
KIRJA-ARVIO
}

\section{JULKINEN KESKUSTELU HALLINNON MUOTONA}

KAURANEN, RALF 2008: Seriedebatt i 1950-talets Finland. En studie i barndom, media och reglering. Åbo: Åbo Akademis förlag. 445 sivua.

\section{$\underline{\text { Helena Saarikoski }}$}

Ralf Kaurasen sosiologian väitöskirja käsittelee 1950-luvun suurta suomalaista sarjakuvakeskustelua yhtenä esimerkkinä lasten ja median välisten suhteiden säätelystä ja hallintorationaalisuudesta (regementalitet, Foucault'n alkuperäistermistä gouvernementalitê), joka näissä alati toistuvissa julkisissa debateissa kehkeytyy. Tutkimus pureutuu perusteellisesti aiheeseen, jollainen koskettaa varmaan minkä hyvänsä modernin kansankulttuurin ilmiön tutkijaa: ilmiöstä käytyyn julkiseen kamppailuun ja viralliseen sääntelyyn, joissa kurittoman kansan hallinnoimisen, normaalistamisen ja valistamisen pyrkimykset saavat ilmauksensa. Esimerkkeinä voi mainita Hilkka Helstin väitöstutkimuksen Kotisynnytysten aikaan (2000), joka keskittyy kansannaisten konflikteihin 1900-luvun alkukymmenien äitiysvalistuksen kanssa, ja saman aikakauden työväestön moraalisäätelyä edustavan tanssikeskustelun, jota on sivuttu useissakin tutkimuksissa (esim. Koskela 2002, 117-128; Salmi-Niklander 2004, 254-255).

Ralf Kaurasen tutkimus ei käsittele oikeastaan lapsia, vaan sitä, miten aikuiset ovat määritelleet lapsuutta ja lasten mediasuhteen, tässä tapauksessa sarjakuvasuhteen, hyvää ja pahaa, väärää ja oikeaa. Laaja tutkimusaineisto koostuu julkisista teksteistä, eritasoisista mielipide- ja asiakirjoituksista, ja arkistoteksteistä, kuten komiteamietinnöistä, eduskunnan asiakirjoista ja lastensuojelujärjestöjen Parasta lapsille ry:n ja Mannerheimin lastensuojeluliiton aineistoista. Tutkimusaineistoon kuuluu myös 1950-luvun tutkimuskirjallisuutta, joka käsittelee tai sivuaa "sarjakuvaongelmaa".

Lasten omat näkemykset tai kokemukset tulevat esiin vain muutamassa harvassa aineistositaatissa. Tutkimuksessa on käsitelty kuitenkin kuva-aineistoa, jossa on tois- 
takymmentä valokuvaa tai piirrosta sarjakuvia lukevista lapsista tai nuorista. Kuvat julkaisuyhteyksineen edustavat aikuisnäkökulmaa siinä missä tutkitut tekstitkin. Kaurasen kirja alkaa oivaltavalla analyysilla kansikuvaksi valitusta valokuvasta, jossa kaksi poikaa istuu ja lukee 1950-lukulaisen pyöreän pöydän ääressä yleisessä kirjastossa, toinen piccolo-sarjakuvalehteä, joka on ehkä hämäystarkoituksessa asetettu luettavaksi isomman kirjan aukeamalle, ja toinenkin kuvakirjaa. Sarjakuviin ja yleensä kuviin uppoutumisen nähdään ehkä vievän lasten huomion tärkeämpiin teksteihin keskittymiseltä, mutta yhtä kaikki pojat viettävät aikaansa kirjastossa. Kansikuvassa nähdään sarjakuvan lukija, kasvava lapsi tai nuori, jonka lukemastaan saamiin vaikutteisiin huolehtiva katse kohdistuu. Kauranen käsittelee tutkimuksessaan näitä arvolatauksia nyansoiden ja tarkasti lähteiden avulla dokumentoiden, monipuolisesti ja ottamatta itse tutkimassaan keskustelussa kantaa puolesta tai vastaan.

\section{SUURI SUOMALAINEN SARJAKUVAKESKUSTELU}

Kaurasen tutkimuksen teoreettis-metodologinen ja kontekstualisoiva johdanto on väitöskirjan tapaan pitkä, mutta lukijan palkitseva. 1950-luvun suomalainen sarjakuvakeskustelu asetetaan sekä kansainväliseen, yllättävän laajaan sarjakuvakeskustelujen yhteyteen että suomalaisen sarjakuvan, sarjakuvalehtien ja niiden lukemisen historian yhteyteen. Tutkimuksellisena kontekstina esiintyy kokonainen lasten ja median suhteen tutkimustraditio; tutkittu 1950-luvun keskustelu määrittelee sarjakuvan lukijan juuri "lapseksi ja nuoreksi".

Teoriaosuudessa Kauranen lähtee liikkeelle paljon käytetystä moraalipaniikin käsitteestä, jonka hän kuitenkin tutkinnan jälkeen hylkää analyysivälineenä: paniikin käsitteeseen sinänsä sisältyy patologisoivia ja moralisoivia oletuksia liioittelemisesta ja joukkosuggestiosta, tuhoavasta demonisoinnista. Kaurasen näkökulma on pikemminkin siihen, mitä suuri sarjakuvakeskustelu tuotti. Tämän aspektin tavoittaa moraalisäätelyn käsite ja sen sisällyttävä foucaultilainen hallintoanalytiikka. Keskeiseksi teoreettis-metodologiseksi periaatteeksi nousee problematisointi. Tutkimustuloksena esitetään (johtopäätösluvun otsikon mukaan) "sarjakuvakeskustelun problematisointeja" sanaparin kahdessa merkityksessä. Tutkimus kuvaa sitä, millaisiksi keskustelussa tuotettiin lasten sarjakuvien lukemisen muodostamaa ongelmaa ja sen ratkaisumalleja sekä tietorakenteita sarjakuvasta ja lapsuudesta. Toisella tasolla tutkimus problematisoi keskustelua, sen tuottamia subjektiasemia, itsestäänselvyyksiä ja kiistakysymyksiä, keskustelussa tuotettuja tieto-valta-rakenteita.

Kirjan viisi aineistoa analysoivaa lukua käsittelevät sarjakuvan määritelmiä, lapsuuden konstruktioita ja erojen tuottamista lapsuuteen (kolme jakolinjaa suhteessa sarjakuvaan olivat keskustelun mukaan sukupuoli, kehitysaste ja normaalius tai poikkeavuus), lastensuojelujärjestöjen tutkimus- ja valistustoimintaa, valtiollisia keskusteluja ja mietintöjä sekä lopuksi sarjakuvaongelman sääntelyehdotuksia. Tärkeässä asemassa keskustelun tiedontuotannossa olivat, ilahduttavaa kyllä, tieteelliset tutkimukset. Niitä käynnistettiin, koska sarjakuvien vahingollisuudesta ei vallinnut yksimielisyyttä eikä ongelman mikään ratkaisulinja saanut totuuden monopoliasemaa. Välineen erottaminen viestistä johti myös vaatimuksiin paremmista sarjakuvista. 1950-luvun suuressa 
sarjakuvakeskustelussa koko laji yhtäältä leimattiin roskaksi, mutta toisaalta siinä luotiin myös pohja nykyiselle ymmärrykselle sarjakuvasta taidemuotona ja välineenä muiden joukossa. Kaurasen tutkimustuloksena on osoittaa, että sarjakuvakeskustelu oli itse sitä sääntelyä, jota siinä vaadittiin, mutta josta sen päätöksenä luovuttiin.

\section{TUTKIMUS KORKEAKULTTUURISTEN KESKUSTELUJEN KENTÄSSÄ}

Lapsuuden aikuislähtöistä määrittelyä ja sääntelyä joudutaan väistämättä käsittelemään myös sellaisissa tutkimuksissa, joissa näkökulma on lasten omiin kokemuksiin kulttuurissaan ja joissa pyritään kuvaamaan lasten omia tulkintoja ja näkemyksiä. Lapset kun eivät asusta erillisissä lastenkulttuurireservaateissa eivätkä muodosta omaa "viimeistä villiheimoaan". Ajattelen paitsi tutkimustani Spice Girlsin fanikulttuurista (Saarikoski 2009), jonka aihe onkin lasten mediasuhteissa, myös esimerkiksi Anna Anttilan väitöstutkimusta varhaisnuorten romanttisesta kulttuurista, johon aikuisten sääntelevä huoli kohdistuu (Anttila 2009, varsinkin Anttila 2005).

Ralf Kaurasen tutkimus on tervetullut ja tärkeä esimerkki siitä, miten aikuiskulttuurin lapsuuteen kohdistamaa märittelyä voidaan kartoittaa ja keskustelua analysoida systemaattisesti alkuperäislähteissä. Yhteen ajallisesti, paikallisesti ja aiheen puolesta rajattuunkin julkiseen keskusteluun kohdistuvana tutkimustehtävä on haastavan kokoinen. Kauranen onnistuu luomaan vakuuttavan kattavan, yksityiskohdista rakentuvan yleiskuvan aiheestaan. Samalla hän osoittaa myös, että tällainen julkinen keskustelu on yksinään enemmän kuin riittävä aihe yhdelle erillistutkimukselle. Lasten oman kulttuurin tutkimuksessa aikuisten tutkimusaiheesta käymä keskustelu on melkeinpä pakko rajata varsinaisena tutkimuskohteena pois. Sitä, miten tutkimuskohde määrittyy tällaisissa keskusteluissa, ei toisaalta voi sivuuttaakaan. Kaurasen tutkimuksen kaltainen peruskartoitus on siksi ehdoton apuneuvo sille, jonka on asemoitava lastenkulttuurin tutkimustaan korkeakulttuuristen lapsuuskeskustelujen kentässä, ja muutettavat muuttaen jokaiselle, joka tekee tutkimusta samantapaisessa keskustelujen kentässä.

\section{OPPIA HISTORIASTA - TAI EI}

Ralf Kauranen esittää toivomuksen, että hänen tutkimuksellaan olisi sanottavaa myös nykyajan lasten ja median suhteista keskusteleville. Suuri sarjakuvakeskustelu tuntuu nykylukijasta monta kertaa naurettavalta ajankohtaisten kovasanaisten lapsuuskeskustelujen rinnalla, lapsuuden seksualisoimisen, pornoistamisen, virtualisoimisen ynnä muun viattomuuden raiskaamisen rinnalla. Kovat puheet ovat muokanneet maaperän myös koville otteille, kuten muun muassa taiteilija Ulla Karttusen näyttelystään saama rikostuomio osoittaa (ks. Jyränki \& Kalha 2009; julkista reaktiota Neitsythuorakirkkoon kuvataan moraalipaniikin käsittein).

On hieman hyytävää, miten samanlaisina, jopa täysin samansisältöisinä sarjakuvakeskustelun argumentit ja asetelmat ovat toistuneet puolen vuosisadan ajan. Jokainen uusi joukkotiedotusväline, niin painettu kirja, sarjakuva, äänilevy, elokuva, televisio kuin internet, lienee saanut vuorollaan osansa suuresta sääntelykeskustelusta. Kaura- 
sen tutkimus esittää, että historiasta pitäisi oppia, mutta valitettavasti se antaa myös ymmärtää, miksi siitä ei haluta oppia. Keskustelussa tuotetaan poliittista valtaa, josta määritellyn ongelman asiantuntijoiksi ja haltuun ottajiksi ilmoittautuvat eivät suinkaan ole halukkaita luopumaan jättääkseen viimeisen sanan sille, joka heidät on nostanut valtaan, itse keskustelulle.

\section{KirjallisuUs}

ANTTILA, ANNA 2005: "Mulla se alko aina diskossa sillee jos tanssii sen kanssa". Varhaisnuorten diskot romanttisen kulttuurin näyttämönä. - Saarikoski, Helena (toim.), Leikekikentiltä. Lastenperinteentutkimuksia 2000-luvulta. Tietolipas 208. Helsinki: SKS.

- 2009: Leikin asia. Näkökulmia varbaisnuorten romanttiseen seurustelukulttuurïn. Helsinki: Yliopistopaino. Helsingin yliopiston sähköinen väitöskirja [online] < https:// oa.doria.fi/handle/10024/46858 > [12.2.2009.]

HELSTI, HILKKA 2000: Kotisynnytysten aikaan. Etnologinen tutkimus äitiyden ja ä̈tiysvalistuksen konflikteista. Suomalaisen Kirjallisuuden Seuran Toimituksia 785. Helsinki: SKS.

JYRÄNKI, JUULIA \& KALHA, HARRI 2009: Tapaus Neitsythuorakirkko. Helsinki: Like.

KOSKELA, KARI 2002: Huligaanit. Katuelämää Sörkassa suurlakosta sisällissotaan. Suomalaisen Kirjallisuuden Seuran Toimituksia 870. Helsinki: SKS.

SAARIKOSKI, HELENA 2009: Nuoren naisellisuuden koreografioita. Spice Girlsin fanit tyttöyden tekijöinä. Suomalaisen Kirjallisuuden Seuran Toimituksia 1230, Tiede. Helsinki: SKS.

SALMI-NIKLANDER, KIRSTI 2004: Itsekasvatusta ja kapinaa. Tutkimus Karkekilan työläisnuorten kirjoittavasta keskusteluybteisöstä 1910- ja 1920-luvuilla. Suomalaisen Kirjallisuuden Seuran Toimituksia 967. Helsinki: SKS.

\section{Folkloristiikan ja naistutkimuksen dosentti, filosofian tohtori Helena Saarikoski on helsinkiläinen vapaa tutkija.}

